\title{
Pengembangan Media Pembelajaran Berbasis Flash Flip Book pada Mata Kuliah Elemen Mesin 1 di Program Studi Pendidikan Teknik Mesin Universitas Sriwijaya
}

\author{
Edi Setiyo $^{1 *}$, Zulhermanan ${ }^{2}$ dan Harlin ${ }^{1}$ \\ ${ }^{1}$ Program Studi Pendidikan Teknik Mesin, FKIP, Unsri \\ ${ }^{2}$ Program Studi Pendidikan Fisika, FKIP, Unsri \\ *Corresponding author, e-mail: edisetiyo@ unsri.ac.id
}

\begin{abstract}
Abstrak - Pengembangan Media Pembelajaran Berbasis Flash Flip Book Pada Mata Kuliah Elemen Mesin 1 Di Pogram Studi Pendidikan Teknik Mesin Fkip Unsri. pengembangan di lakukan dengan model Rowntree. Eveluasi dilakukan dengan menggunakan metode evaluasi formatif tessmer. Data dikumpulkan melalui validasi, angket, dan wawancara. Hasil penelitian menunjukan bahwa kevalidan materi adalah $90,27 \%$ dengan kategori valid, desain sebesar $86 \%$ dengan kategori sangat valid. Dengan demikian produk memiliki validitas sebasar 83,75\% dengan kategori sangat valid. Skor kepraktisan pada tahap one-to-one evaluation sangat praktis terlihat dari komentar dan saran yang menunjukan komentar dan saran yang baik, tahapan small group evaluation sebesar $83,75 \%$ dengan kategori praktis, dan tahapan field test sebesar $82,41 \%$ dengan kategori praktis. Dengan demikian, produk berupa media flas flip book berkualitas baik sehingga dapat diterapkan dalam pembelajaran elemen mesin 1.
\end{abstract}

Kata kunci : media pembelajaran flash flip book, pengembangan, valid dan praktis.

\begin{abstract}
Based Learning Media Development Flash Flip Book On Course Element 1 In pogram Studies Engineering Mechanical Engineering Education FKIP Unsri. development is done with the model Rowntree. Evaluating performed using tessmer formative evaluation. Data were collected through validation, questionnaires, and interviews. The results showed that the validity of the material is $90,27 \%$ with a valid category, amounting to $86 \%$ of design premises very valid category. Thus the product has validity sebasar $83,75 \%$ categorized as very valid. Scores of practicality at the stage of one-to-one very practical evaluation seen from the comments and suggestions that show good comments and suggestions, the stages of evaluation of a small group of 83,75 with practical categories and stages of a field test of $82,41 \%$ denag practical category. Thus, the product of the media flas good quality flip book so that it can be applied in teaching machine element 1.
\end{abstract}

Keywords : teaching media flash flip book, development, valid and practical.

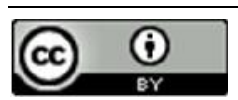

This is an open access article distributed under the Creative Commons 4.0 Attribution License, which permits unrestricted use, distribution, and reproduction in any medium, provided the original work is properly cited. (C2018 by Author and Universitas Negeri Padang

\section{Pendahuluan}

Kemajuan dan peranan teknologi saat ini telah mengalami perkembangan semakin pesat, sehingga penggunaan alat-alat perlengkapan pendidikan, media pendidikan dan pengajaran di sekolahsekolah mulai disesuaikan dengan kemajuan. Hal inilah yang menyebabkan tuntutan sumber daya manusia yang berkualitas semakin meningkat, untuk meningkatnya sumber daya manusia maka dapat dilaksanakan dengan adanya peran pendidikan.

Peranan pendidikan pada pembangunan, merupakan hal yang sangat menentukan. Setiap gerak pembangunan memerlukan inovasi pengetahuan, keterampilan serta pengembangan sikap. Dimana pengembangan itu dapat ditempuh melalui proses pendidikan. Pendidikan berperan sangat penting dalam kelancaran hidup suatu bangsa.

Dalam proses pendidikan tidak terlepas dengan adanya proses belajar dan mengajar sehingga dalam proses pembelajaran sangat diperlukan adanya komunikasi yang baik antara pemberi pesan dengan penerima pesan hal ini dapat diartikan sebagai komunikasi dua arah yang saling berkaitan. bentuk komunikasi pembelajaran dua arah sangat memerlukan adanya media. 
Pembelajaran yang baik serta berkualitas menuntut siswa tidak hanya berperan sebagai penerima pesan saja melainkan berperan sebagai penyampai pesan. Untuk meningkatkan ke efektifan dalam pencapaian kompetensi proses pembelajaran sangat diperlukan peranan dari media [7].

Ilmu pengetahuan teknologi saat ini semakin maju dengan adanya kemajuan ilmu pengetahuan dan teknologi tersebut maka saat menggunakan media pembelajaran dalkam proses belajar mengajar disesuaikan dengan perkembangan pendidikan. Dalam proses pembelajaran siswa diharapkan dapat menerima informasi serta ilmu pengetahuan yang disampaikan oleh guru dengan baik. Dalam proses menyampaikan materi pembelajaran lebih mudah dengan memanfaatkan media pembelajaran sebagai sarana untuk menunjang peserta didik dalam memahami materi pelajaran secara maksimal.

Selain merencanakan media pembelajaran yang baik seorang pendidik juga harus mampu mengembangkan keterampilannya untuk membuat alat bantu pengajaran. Alat bantu pengajaran yang di sesuaikan dengan kondisi perguruan tinggi serta keadaan mahasiswanya. Supaya proses blajar mengajar dilakukan dengan maksimal pendidik juga harus merancang proses belajar mengajar yang melibatkan anak didik secara baik.

Setelah peneliti mendapat gagasan untuk mengembangkan media berbentuk flas flip book, peneliti melakukan observasi kepada dosen pengampu matakuliah elemen mesin 1 yang menyatakan bahwa media flash flip book perlu dikembangkan lebih lanjut sebagai penunjang proses perkuliahan. Media pembelajaran flash flip book sendiri dapat digunakan di kelas, walaupun terdiri dari satu siswa masih efektif media ini digunakan.

Berdasarkan dari uraian di atas, peneliti tertarik untuk membuat sebuah media berupa flash flip book yang dapat menunjang proses perkuliahan di program studi pendidikan teknik mesin.

\section{Studi Pustaka}

\section{A. Pengertian Penelitian dan Pengembangan}

Penelitian dan pengembangan yaitu sebuah strategi yang diaplikasikan dalam proses pembelajaran serta bukan hanya untuk memperbaiki suatu produk melainkan memperbaharui suatu produk yang belum ada sebelumnya, produk yang dikembangkan tersebut terlebih dahulu harus valid dan praktis sehingga membuat pembelajaran lebih menarik [7]. Selanjutnya pengertian penelitian dan pengembangan pengembangan adalah penelitian yang memiliki tujuan untuk menyempurnakan produk yang belum ada atau membuat, menciptakan hasil karya baru dan hasil karya yang dciptakan tersebut tidak harus berbentuk benda tetapi dapat juga berbentuk aplikasi. [2] .

Berdasarkan pendapat ahli di atas, maka dapat peneliti simpulkan penelitian pengembangan merupakan suatu penelitian yang dapat membuat produk baru maupun mengembangkan produk yang sudah ada, selanjutnya dilakukan Uji validitas dan kepraktisan produk tersebut supaya dapat digunakan dalam proses pembelajaran.

Bagian Studi Pustaka merupakan bagian optional. Bagian ini membahas teori dasar dari penelitian, yang dianggap penting untuk dikemukakan. Bagian ini juga membahas penelitian-penelitian lain yang relevan dengan penelitian yang dikemukakan pada naskah ini. Bagian Studi Pustaka boleh tidak ada, jika teori dasar/penelitian relevan bisa diintegrasikan pada bagian Pendahuluan.

\section{B. Media Pembelajaran}

Media ditinjau dari sifatnya dibagimenjadi dua, pertama media cetak seperti bulletin, majalah, brosur, yang ke dua media elektronik seperti televisi, radio, website [3].

Selanjutnya media pembelajaran merupakan alat bantu dalam proses belajar mengajar guna meningkatkan semangat serta perhatian siswa sehingga ada kemauan untuk lebih semangat dalam mengikuti suatu proses pembelajaran [1].

Dari uraian para ahli di atas disimpulkan bahwa segala sesuatu yang bisa digunakan sebagai perantara dalam menyampaikan materi maupun pengetahuan saat proses belajar mengajar berlangsung dapat diartikan sebagai media pembelajaran.

Media pembelajaran memiliki fungsi meningkatkan mutu proses dalam pembelajaran, dalam proses pembelajaran harus melibatkan mahasiswa selanjutnya informasi yang ada pada media harus melibatkan mahasiswa dalam berfikir, supaya proses pembelajaran dapat terlaksana. Disamping media dapat menjadi alat bantu, memberikan motifasi dalam belajar media juga sebagai sumber belajar.

secara umum media pembelajaran berguna untuk: (1) menjelaskan materi yang akan disampaian supaya mudah difahami (2) meminimalisir penggunaan ruang, waktu, tenaga dan daya indera (3) Menimbulkan motifasi belajar, interaksi dapat berjalan baik karena mahasiswa berinteraksi langsung dengan sumber belajar [4]. 
Berdasarkan pendapat ahli di atas disimpulkan bahwa media pembelajaran memiliki manfaat serta memiliki peran yang penting guna menunjang terciptanya suasana belajar yang baik serta proses belajar yang menarik, merangsang siswa untuk berfikir dan beranalisis sehingga tidak hanya dengan komunikasi verbal saja saat menyampaikan materi sehingga dengan adanya peran dari media pembelajaran harapan yang terkandung dalam proses belajar mengajar dapat tercapai.

Media pembelajaran dikelompokkan menjadi 6 jenis yaitu: media grafis, media proyeksi diam, media audio, media audio visual diam, video, televisi [4]. Media pembelajaran di kelompokkan berdasarkan ciri-ciri persamaan dan perbedaan menjadi tujuh kelompok diantaranya gambar bergerak, gambar diam, media cetak, komunikasi lisan, film bersuara, mesin belajar dan benda yang didemonstrasikan [5].

Berdasarkan pendapat ahli di atas dapat disimpulkan bahwasanya pemilihan media tidak terlepas dari tujuan pembelajaran, materi perkuliahan yang akan disajikan dalam proses pembelajaran, karakteristik pembelajaran dapat menunjang terciptanya efisiensi dan efektifitas proses dan hasil belajar yang baik.

\section{Cara Membuat E-book dengan Kvisoft Flip Book Maker}

Langkah pertama mendownload software flip book maker selanjutnya install pada computer yang telah disediakan.

Langkah kedua buka aplikasi yang sudah di install kemudian siapkan file berbentuk pdf, kemudian klik Add file, begitu juga jika ingin memasukkan gambar dan video dapat di masukkan pada langkah ke dua ini.

Langkah ketiga agar tampilannya baik sesuaikanlah bentuk yang diinginkan dengan cara memilih stile. Langkah keempat, jika sudah sesuai dengan stile yang diinginkan selanjutnya tekan perintah publish selanjutnya aplikasi flip book maker sudah dapat digunakan.

\section{Aplikasi Martview Dalam Pembuatan E-Book}

Martview merupakan aplikasi untuk membuat ebook, yang dapat membuka file. Seperti kita membuka buku nyata. Aplikasi ini tergolong sangat menarik, setiap orang yang ingin menggunakan aplikasi MartView diberikan secara gratis atau free. Pada saat martview diinstall, computer harus terhubung internet karena akan mengunduh file guna mendukung kinerja martview tersebut. Jika proses install selesai, aplikasi secara otomatis akan terbuka dengan tampilan horizontal vertikal slide.

Kelebihan lain dari aplikasi MartView adalah untuk membuka file dengan format pdf, jpg, zip, rar, membuat dokumen seperti layaknya majalah hanya dengan convert file, baik dari pdf maupun documen. Secara umum, ada beberapa fitur yang ada dalam aplikasi MartView ini, antara lain: pdf, jpg, rar, zip, touch screen, membaca disertai efek flip, unduh, upload, vertical file. Horizontal slide. Langkah-langkah Pembuatan (1) Menginstal program utama dalam membangun e-book. Instal program $3 D$ flipbook professional. (2) Sebelum memasuki program utama. Persiapkan dahulu bahan ajar yang akan diubah menjadi e-book. (3) Bahan ajar yang telah disiapkan didalam Microsoft word haruslah berupa bahan ajar yang telah selesai. Sebuah ruang (space) disiapkan di dalam file tersebut agar dapat diisi dengan file berbentuk Video ataupun animasi melalui program utama. (4) Setelah semua sudah selsai convert file tersebut menjadi file berbentuk PDF. (5) Buka program $3 D$ flipbook professional. Pilih pilihan "create New" selanjutnya pilih "custom range" untuk memilih halaman tertentu. Setelah itu "import Now" (6) Setelah itu, akan muncul file yang akan diubah menjadi e-book. (7) Untuk menambahkan file video atau animasi, tekan "edit paged". (8) Kemudian, Pilih halama yang telah kita siapkan untuk ditambahkan file video atau animasi, selanjutnya Pilih "add movie" untuk menambahkan file video. Kemudian pilih area yang akan dijadikan tempat video diputar. Kemudian atur pengaturan video. Pilih "video path" untuk memilih video yang akan dimasukan kedalam file ebook (pastikan file video berformat MP4). Atur juga pengaturan mulainya video, lihat "when to play" kemudian pilih "when click play button" yang bearti video akan diputar ketika diklik dan lihat "when to stop" kemudian pilih "when leave the page" yang bearti video akan berhenti ketika berpindah halaman. (9) Kemudian pilih menu "file" dan pilih "save and exit".(10) Maka tampilan akan menuju tampilan awal. Kemudian silakan dicek kembali ebook yang telah jadi tersebut. (11) Jika file dirasa sudah cukup, maka terakhir akan kita publikasikan. Pilih menu "publish" selanjutnya klik EXE. (12) Maka akan muncul tab baru. Pada bagian Output Folder, tekan "browse" untuk menentukan letak file yang siap pakai di windows explore. Jangan lupa pula ubah nama file sesuai dengan keinginan. Kemudian terakhir tekan tombol Convert (13) Selesai Ebook siap dipakai untuk pembelajaran yang lebih menarik. 


\section{METODE}

\section{A. Jenis Penelitian}

Jenis penelitian ini merupakan penelitian pengembangan yang lebih dikenal dengan $R \& D$ (Research and Development). Yang bertujuan untuk menghasilkan media yang bersifat valid, praktis [6]. Metode penelitian ini untuk mengetahui apakah media yang dikembangkan dalam proses pembelajaran sudah valid dan praktis. Penelitian ini dilakukan di Program Studi Pendidikan Teknik Mesin, FKIP, Unsri. Tahun Ajaran 2016/2017.

Objek penelitian ini adalah media pembelajaran berbasis flash flip book pada mata kuliah elemen mesin di Program Studi Pendidikan Teknik Mesin FKIP Unsri. Subjeknya adalah Mahasiswa FKIP Pendidikan Teknik Mesin.

\section{B. Teknik Pengumpulan Data}

Untuk memperoleh data validasi media flash flip book, digunakan penilaian ahli. Alat pengumpulan data yang digunakan berupa lembar validasi yang diberikan pada ahli. Lembar validasi digunakan untuk memvalidasi media flas flip book pada matakuliah elemen mesin 1 yang telah dikembangkan untuk memperoleh penilaian dan tanggapan berupa komentar dan saran dari para ahli tentang media flash flip book, baik pada aspek isi materi maupun desain media.

Peneliti memberikan angket kepada mahasiswa terhadap keterpakaian media flash flip book untuk melihat kepraktisan media berbasis flash flip book pada matakuliah elemen mesin 1. Data angket ini dalam bentuk Checklist dengan menggunakan skala Likert. Angket diberikan setelah uji coba pada tahap Small group dan Field test.

Data hasil wawancara penelitian yang dilakukan secara terbuka dan tidak terstruktur dianalisis secara deskriptif sebagai acuan revisi produk apabila diperlukan untuk revisi. Wawancara pertama dilakukan peneliti pada saat analisis kebutuhan, selanjutnnya dilakukan pada tahap oneto-one. Wawancara dilakukan kepada beberapa mahasiswa untuk dengan tujuan untuk menggali permasalahan dalam pembelajaran mata kuliah elemen mesin 1.

\section{Analisis Data Angket}

Angket digunakan untuk mengambil data selanjutnya data dianalisis menggunakan skala likert untuk mengukur pendapat mahasiswa terhadap penggunaan media pembelajaran berbasis flash flip book. Data hasil angket yang diperoleh dihitung dengan rumus yang digunakan untuk menghitung skor adalah sebagai berikut: Jumlah skor per item $=$ jumlah responden yang menjawab x skor jawaban.

\section{Analisis Data Wawancara}

Data hasil wawancara yang dilakukan secara terbuka dan tidak terstruktur dianalisis secara deskriptif kualitatif, hasil wawancara pada one-toone evaluation dijadikan sebagai acuan untuk merevisi produk.

\section{HASIL DAN PEMbahaSAN}

Penelitian pengembangan ini bertujuan untuk menghasilkan media pembelajaran berbasis flash flip book yang valid dan praktis. Pada penelitian ini model pengembangan yang digunakan yaitu model pengembangan produk Rowntree dan metode evaluasi Tessmer. Tiga tahapan dalam penelitian ini diantaranya: tahap pendahuluan, tahap pengembangan serta tahap evaluasi.

Tahap pendahuluan mencakup identifikasi masalah yang timbul selama kegiatan pembelajaran berlangsung serta mencari solusinya. Selanjutnya tahap pengembangan kegiatan yang dilakukan membuat desain produk. Media pembelajaran flash flip book yang telah didesain, Selajutnya akan dievaluasi kevalidannya.

Kevalidan produk dari hasil penilaian tiga ahli yaitu ahli content (isi media), ahli materi dan ahli bahasa. Berdasarkan uji validasi content kepada Bapak H. Imam Syofii, S.Pd., M.Eng, materi pembelajaran flash flip book layak diuji cobakan tanpa revisi. Menurut ahli Bahasa Ibu Armilia Sari, S.Pd., M.Pd, ada beberapa saran revisi yaitu memperbaiki penulisan bahasa asing dan tanda baca pada materi, sedangkan menurut ahli desain oleh Bapak Sulki Pani S.Pd., M.Pd media layak diuji cobakan dengan revisi, ada beberapa saran ahli untuk merivisi desain meliputi tampilan, video, tulisan yang kurang jelas (kabur).

Untuk mengetahui kekurangan atau kelemahan media pembelajaran yang dikembangkan, draf awal media diuji cobakan kepada mahasiswa pada tahap evaluasi orang per orang, uji coba orang per orang dilakukan terhadap sembilan mahasiswa angkatan 2015 Program Studi Pendidikan Teknik Mesin Kampus palembang, peneliti meminta mahasiswa untuk menggunakan media pembelajaran flas flip book materi elemen mesin 1. Selanjutnya peneliti meminta mahasiswa memberikan komentar dan saran yang nantinya akan peneliti jadikan dasar tindakan revisi.

Draf awal media yang sudah dinyatakan valid dan direvisi, selanjutnya akan diuji cobakan pada tahap uji coba kelompok kecil (small group). Uji 
coba ini dilakukan untuk melihat kepraktisan yang terdiri dari dua belas orang mahasiswa angkatan 2015 Program Studi Pendidikan Teknik Mesin kampus Palembang, setiap mahasiswa dipersilahkan untuk menggunakan media pembelajaran falsh flip book materi elemen mesin 1. Selanjutnya peneliti meminta mahasiswa mengisi angket untuk melihat kepraktisan media. Rata-rata persentase skor angket yang dipoleh pada tahap small group yaitu $83,75 \%$, persentase ini berada dalam kategori baik. Uji coba lapangan (field test) dilakukan dengan mahasiswa pendidikan teknik mesin angkatan 2015 kelas indralaya yang berjumlah 37 orang. Pada tahap ini mahasiswa diberikan 10 soal tes pertama yaitu pre test dalam tes ini mahasiswa langsung diberi lembar soal selanjutnya peneliti mempersilahkan mereka menjawab soal. Setelah dilakukan pre test didapat presentase kelulusan sebesar $45.94 \%$ dalam kategori tidak lulus. Selanjutnya setelah dilaksanakan pre test peneliti melakukan post test pada tahap ini mahasiswa dipersilahkan mempelajari media berbasis flash flip book yang peneliti kembangkan. Setelah media selsai di tayangkan menggunakan LCD maka peneliti langsung memberikan lembar soal post test dengan 10 soal test yang sama jika sudah selesai selanjutnya dilakukan koreksi jawaban. Diperoleh presentase kelulusan meningkat menjadi $83.78 \%$ dalam kategori lulus. Artinya media flash flip book yang peneliti kembangkan bisa meningkatkan hasil belajar mahasiswa.

Setelah selesai melakukan tahap evaluasi dapat disimpulkan bahwa media pembelajaran menggunakan flash flip book telah valid dan praktis untuk digunakan dalam proses pembelajaran.

\section{KESIMPULAN}

Berdasarkan analisis data dan pembahasan sehingga dapat disimpulkan bahwa media pembelajaran menggunakan flash flip book pada matakuliah elemen mesin 1 yang dikembangkan peneliti menghasilkan media pembelajaran yang valid serta praktis untuk diterapkan pada proses pembelajaran. Kevalidan dilihat dari hasil validasi ahli materi, ahli bahasa serta ahli media. Berdasarkan hasil dari penilaian ahli materi diperoleh hasil persentase sebesar $90.27 \%$ hasil persentase tersebut masuk dalam kategori valid. Sedangkan penilaian ahli media diperoleh hasil persentase sebesar $86 \%$ yang berarti sangat valid. Kemudian kepraktisan media dilihat dari hasil observasi yang dilakukan pada tahap one-to-one small group, serta field test. Berdasarkan analisis observasi menunjukkan bahwa pada uji one-to-one, small group $83,75 \%$ uji lapangan dapat meningkatkan hasil belajar dengan persentase kelulusan sebesar $83.78 \%$ dari sebelumnya $45.94 \%$

\section{DAfTAR PUStaka}

[1] Arsyad, Azhar. 2011. Media Pembelajaran.Jakarta : PT Raja Grafindo Persada.

[2] Munawaroh. 2013. Penelitian Pengembangan http://staff.uny.ac.id (diakses tanggal 30 juni 2016)

[3] Nova, Firsan.2009.Crisis Public Relation. Jakarta: PT.Grasindo.

[4] Riyana, Cepi.2009. media pembelajaran. Jakarta: kementrian agama RI

[5] Sudjana, Nana dan ahmad rivai.2002. Media Pengajaran. Bandung: sinar baru algesindo.

[6] Sugiyono. 2014. Metode Penelitian Pendidikan. Bandung : Alfabeta.

[7] Susilana, R. \& Riyana, C. (2009). Media Pembelajara, hakikat, pengembangan, pemanfaatan, dan nilaian. Bandung: $\mathrm{CV}$. Wacana Prima.

\section{Biodata Penulis}

Edi Setiyo, lahir Sarko, 11 Agustus 1987. Sarjana Pendidikan di Jurusan Teknik otomotif FT UNP 2010. Tahun 2013 memperoleh gelar Magister Pendidikan di jurusan Pendidikan Teknologi dan Kejuruan Program Pascasarjana UNP dengan bidang konsentrasi Pendidikan Kejuruan. Staf pengajar di program studi Pendidikan Teknik Mesin Fakultas Keguruan dan Ilmu Pendidikan Universitas Sriwijaya.

Zulherman, dilahirkan di Pangkal Pinang, 12 Juli 1956. Menyelesaikan pendidikan S1 di IKIP Bandung dan menyelsaikan pendidikan Pascasarjana di Universitas Sriwijaya. Staf pengajar di program studi pendidikan Fisika FKIP UNSRI

Harlin, dilahirkan di Palembang, 1966. Menyelesaikan pendidikan S1 pada jurusan Pendidikan Teknik Mesin IKIP Padang dan pendidikan Pascasarjana (S2) di Universitas Yogyakarta. Staf pengajar di program studi Pendidikan Teknik Mesin Fakultas Keguruan dan Ilmu Pendidikan Universitas Sriwijaya. 
